\title{
The Resettlement of Homeless Young People: Their Experiences and Housing Outcomes
}

\section{Maureen Crane*, Anthony M. Warnes**, Jennifer Barnes ${ }^{* * *}$ and Sarah Coward ${ }^{\dagger}$}

\author{
*Social Care Workforce Research Unit, King's College London \\ E-mail: Maureen_ann.crane@kcl.ac.uk \\ **School of Medicine and Biological Sciences, University of Sheffield \\ E-Mail: a.warnes@sheffield.ac.uk \\ *** Centrepoint, London \\ E-mail: j.barnes@centrepoint.org \\ †Social Care Workforce Research Unit, King's College London \\ sarah.coward@kcl.ac.uk
}

This article reports the experiences of 109 homeless people aged seventeen to twenty-five years in England who were resettled into independent accommodation during 2007/08. It focuses on housing, finances, employment and access to support services. After fifteen/eighteen months, 69 per cent of the young people were still in their original accommodation, 13 per cent had moved to another tenancy and 18 per cent no longer had a tenancy. Most were glad to have been resettled but found the transition very challenging, particularly with regard to managing finances and finding stable employment. The prevalence of debts increased substantially over time, and those who moved to private-rented accommodation had the poorest outcomes. People who had been in temporary accommodation more than twelve months prior to resettlement were more likely to retain a tenancy, while a history of illegal drug use and recent rough sleeping were associated negatively with tenancy sustainment.

Key words: Young people, housing, homelessness, financial problems, unemployment.

\section{Introduction}

Youth homelessness has grown in many affluent countries and is a major social concern (Chamberlain and MacKenzie, 2004; Toro et al., 2007). It interrupts normal socialisation and education, is devastating for personal well-being and can lead to or exacerbate mental health problems, substance misuse and criminality. It may also lead to repeated or chronic homelessness. Moreover, economic difficulties, including high housing costs, major welfare reforms and cuts to services in England, are making it progressively more difficult for vulnerable and disadvantaged young people to achieve independent living.

This article examines the challenges faced by homeless young people when they are resettled and focuses on housing, finances, employment and access to support services. It draws on the experiences of 109 homeless people aged seventeen to twenty-five years in England who were resettled into independent accommodation during 2007/08. They were participants in the FOR-HOME study which examined resettlement outcomes over 
fifteen/eighteen months for single homeless people of all ages. The article begins with summary accounts of youth homelessness, the policy and service responses and the FOR-HOME study.

\section{Youth homelessness}

Homelessness among young people grew markedly during the 1970s and 1980s in many western industrial countries. In the United Kingdom (UK), this was attributed to decreasing numbers of low-skilled jobs, cuts in welfare benefits and a shrinking supply of affordable housing (Hutson and Liddiard, 1994). The problem has recently increased again. The number of under twenty-five-year-olds who slept on the streets in London increased sharply from 318 in 2010/11 to 624 in 2011/12 and 708 in 2012/13 (Homeless Link, 2011; Broadway, 2012, 2013). Quilgars et al. (2011) estimated that 78,000 people aged sixteen to twenty-four years in the UK experienced homelessness at some time during 2008/09, around 1 per cent of the age group. The recent surge has been linked to slow economic growth, more young people not in education, training or employment, changes in welfare and cuts in the youth services that undertake early intervention work with vulnerable young people (Homeless Link, 2011). In Denmark and Germany, labour market reforms, reduced welfare benefits, the increased use of sanctions for benefit recipients and scarce affordable housing have similarly been nominated as causes of rising youth homelessness (Benjaminsen and Busch-Geertsema, 2009).

Many young people who become homeless are from low-income families and were raised in problematic or unstable childhood homes (Mallett et al., 2005; Toro et al., 2007). Many have experienced difficulties at school, lack qualifications and have mental health, alcohol and drug problems (Cauce et al., 2000; Gomez et al., 2010). The most common trigger to their homelessness is family conflict and the breakdown of relationships with parents or step-parents. Other triggers include leaving statutory care or young offenders' institutions (Toro et al., 2007). Young migrants are disproportionately represented among homeless people in the UK, Spain and Portugal (Centrepoint, 2010; Quilgars, 2010).

\section{Policy and service responses in England}

Service responses to youth homelessness tend to be country specific, partly reflecting different configurations of state, local (or regional) government and charitable agencies. The policies, funding streams and working relationships among the agencies are intricate and change frequently. This article necessarily focuses on England, although the service contexts are similar in Scotland, Wales and Northern Ireland. In England, local authorities have a statutory duty to rehouse people who have a local connection and are assessed as 'unintentionally homeless' and in 'priority need'. The Housing Act 1996 defined households in 'priority need' as those with dependent children, and people who are vulnerable because of old age, mental illness, physical disability or domestic violence. The 'priority needs' groups were expanded by the 'Homelessness (Priority Need for Accommodation) (England) Order 2002' to include young people aged sixteen and seventeen years, those aged under twenty-one years who were in local authority care between sixteen and eighteen years of age and people aged twenty-one and over who are vulnerable as a result of having been in local authority care. 
A much larger number of homeless people have, however, not approached local authorities for rehousing or do not fit the priority criteria, and are commonly referred to as 'single homeless people'. Some sleep on the streets but many stay in temporary accommodation, such as shelters, hostels and transitional supported housing, which are funded by the state (mostly through local authorities) and charities. Resettlement programmes for single homeless people have proliferated in England since the late1990s, manifesting successive governments' increasingly assertive policies to tackle homelessness and avoid long-term hostel residence. From 2005, the Hostels Capital Improvements Programme and its successors have made $£ 212 \mathrm{~m}$ available to modernise hostels and help homeless people overcome their problems and prepare for independent living (Department for Communities and Local Government (DCLG), 2006). Family mediation schemes have expanded and supported lodging schemes have been established whereby young people who can no longer live at home stay with a 'host' family (DCLG, 2007; Holmes, 2008).

Various types of temporary accommodation, support and training are available for homeless young people, and some organisations work exclusively with the age group. Centrepoint, for example, started in 1969 as a night-shelter in London for young people sleeping on the streets. It now has hostels, foyers and supported housing, and annually helps over 1,000 young homeless people each year in London and North East England. Foyers provide temporary accommodation for young people with housing and support needs, and help with personal development, education, training and employment (Lovatt et al., 2006). They originated in France, are widespread in Germany and The Netherlands, and were introduced into the UK during the early 1990 s.

\section{Resettlement for homeless young people}

For homeless young people, resettlement involves taking on the responsibilities of a tenancy when unusually young, often without the experience of a secure family home (Fowler et al., 2009; Osgood et al., 2010). Many have experienced family conflicts and are without strong family support. According to Hagan and McCarthy (2005: 178) many homeless young people begin the transition to adulthood before 'they acquire the skills, credentials, experiences, psychological resources, connections, social support and other assets that increase the likelihood of success'. The few studies of their pathways out of homelessness have found that positive outcomes are associated with returning to the family home, engagement in education, training and employment and help from family and professionals (Kurtz et al., 2000; Milburn et al., 2007, 2009; Nebbitt et al., 2007; Mallett et al., 2010; Mayock et al., 2011; Tevendale et al., 2011).

\section{The FOR-HOME study}

The principal aim of the FOR-HOME study was to improve understanding of the experiences of homeless people who are resettled and the factors that influenced the outcomes. The study was designed in collaboration with six homelessness service-provider organisations in London, Leeds, Nottingham and Sheffield (see Acknowledgements). Research ethics approval was granted by the University of Sheffield Research Ethics Committee. The three-year study (2007-10) recruited 400 single homeless people aged sixteen-plus years who were resettled by the collaborating organisations 
into independent accommodation where they were responsible for rent payments, other housing expenses and household tasks. Face-to-face interviews were conducted just before they moved, and after six and eighteen months (for 23 per cent the third interview was at fifteen months because their recruitment had taken longer than planned). Each interview lasted one to two hours, and most were conducted in the participants' homes. Information was collected about housing, homelessness and employment histories; finances and debts; engagement in work, training and activities; health and addiction problems; social networks; the resettlement accommodation; help and support before and after moving; and experiences since resettlement. A questionnaire about preparation for moving was completed by the resettlement worker.

There are no nationally collated statistics on the characteristics of single homeless people who are resettled. To maximise the representativeness of the FOR-HOME sample, data on the clients resettled into independent accommodation during 2006 by the six collaborating organisations were collated as a sample frame. Diligent application by the six organisations of sampling quotas resulted in the age, sex and ethnic profiles of the achieved sample closely matching those of people resettled in 2006, except for a 20 per cent over-representation of men aged thirty-six-plus years and a 27 per cent under-representation of men aged sixteen to twenty-five years. This was because one organisation that worked mainly with homeless men over the age of twenty-five increased their recruitment to achieve the target of 400 (for details see Crane et al., 2011).

\section{The participants' backgrounds}

The findings reported in this article refer exclusively to the 109 FOR-HOME participants aged seventeen to twenty-five years (fifty-five men, fifty-four women). Fifty-nine were in London and fifty in Nottingham, Leeds and Sheffield (collectively Notts/Yorks). All were interviewed at the time of moving, 89 per cent at six months, and 75 per cent at $15 / 18$ months. When rehoused 38 per cent were aged seventeen to nineteen years. Forty-four per cent were White British, the rest from ethnic minority groups, and 25 per cent were born outside the British Isles. They had high rates of personal problems and disadvantages, including having been in care, poor educational attainment, mental health problems and illegal drug use (Table 1). Thirty-eight per cent had been homeless longer than two years and 23 per cent more than once.

There were marked differences in the young people's backgrounds by locality. Most in Notts/Yorks were White British and they were more likely to have had chaotic histories: many had become homeless following arguments with their parents, and they were more likely to have been expelled from school, to have drug problems and to have been homeless several times (Table 1). Most in London were from non-white ethnic groups. For example, seventeen were born in Somalia, Ethiopia or Eritrea and had come to England to escape civil unrest. Some were homeless on arrival in this country, while a few initially stayed with relatives but left the accommodation following arguments. Depression among them was common, but only a minority had drug or alcohol problems.

Most (82 per cent) of the 109 young people had never lived alone. Before being resettled, all were in temporary accommodation: nearly three-quarters were in foyers or 
Table 1 Backgrounds of the young FOR-HOME participants and resettlement preparation by location and age

\begin{tabular}{|c|c|c|c|c|c|}
\hline \multirow[b]{2}{*}{ Characteristics } & \multicolumn{2}{|c|}{ Location } & \multicolumn{3}{|c|}{ Age group (years) } \\
\hline & London & Notts/ Yorks & $17-19$ & $20-25$ & Total \\
\hline & Percentages & & & & \\
\hline White British & 11.9 & $82.0^{* * *}$ & 42.6 & 46.3 & 44.0 \\
\hline In statutory care as a child & 23.7 & 22.4 & 24.4 & 22.4 & 23.1 \\
\hline$\ldots$ for $2+$ years & 8.9 & 16.3 & 15.0 & 10.8 & 12.4 \\
\hline Literacy difficulties & 8.5 & $30.0^{* *}$ & 12.2 & 22.1 & 18.3 \\
\hline Expelled from school & 5.2 & $24.5^{* *}$ & 12.2 & 15.2 & 14.9 \\
\hline No educational qualifications ${ }^{1}$ & 33.9 & 50.0 & 31.7 & 47.1 & 41.3 \\
\hline Homeless $>24$ months & $57.6^{* * *}$ & 14.0 & 24.4 & $45.6^{*}$ & 37.6 \\
\hline Homeless more than once & 11.9 & $36.0^{* *}$ & 12.2 & $29.4^{*}$ & 22.9 \\
\hline Mental health problems ${ }^{2}$ & 50.8 & 46.0 & 26.8 & $61.8^{* * *}$ & 48.6 \\
\hline Alcohol problems ${ }^{2}$ & 20.3 & 18.0 & 7.3 & $26.5^{*}$ & 19.3 \\
\hline Illegal drug use ${ }^{2}$ & 35.6 & $64.0^{* *}$ & 43.9 & 51.5 & 48.6 \\
\hline ... drugs other than cannabis & 6.8 & $56.0^{* * *}$ & 24.4 & 32.4 & 29.4 \\
\hline \multicolumn{6}{|l|}{ Resettlement preparation } \\
\hline Slept rough in last 12 months $^{3}$ & 3.4 & $20.4^{* *}$ & 7.5 & 13.2 & 11.1 \\
\hline In last hostel/project $>6$ months $^{3}$ & $88.1^{* * *}$ & 38.0 & 61.0 & 67.6 & 65.1 \\
\hline In supported housing $>12$ months $^{3}$ & $79.7^{* * *}$ & 28.0 & 53.7 & 57.4 & 56.0 \\
\hline In semi-independent accommodation ${ }^{3}$ & $82.1^{*}$ & 61.2 & 75.0 & 70.8 & 72.4 \\
\hline Training on preparing meals & 40.7 & 40.0 & $56.1^{* *}$ & 30.9 & 40.4 \\
\hline Training on paying bills & 55.9 & 40.0 & $65.9^{* *}$ & 38.2 & 48.6 \\
\hline Training on budgeting & $57.6^{*}$ & 38.0 & 53.7 & 45.6 & 48.6 \\
\hline Has debts at resettlement & 42.4 & 44.0 & 29.3 & $51.5^{*}$ & 43.1 \\
\hline $\mathrm{NEET}^{4}$ at resettlement & 35.6 & $78.0^{* * *}$ & 46.3 & 60.3 & 55.0 \\
\hline Number of participants & 59 & 50 & 41 & 68 & 109 \\
\hline
\end{tabular}

Notes: Significance levels are for chi-squared tests of the $2 \times 2$ location and age comparisons (1 degree of freedom): ${ }^{* * *} p<0.001,{ }^{* *} p<0.01,{ }^{*} p<0.05$.

${ }^{1}$ No General Certificate of Secondary Education or equivalent.

${ }^{2}$ Currently or in the past.

${ }^{3}$ Immediately before being resettled.

${ }^{4}$ NEET: Not in education, training or employment.

supported housing where they were responsible for cooking and cleaning, and the rest were in hostels where subsidised meals were provided. Some attended workshops or received one-to-one training on preparing meals, looking after a home, budgeting and paying bills. Those aged seventeen to nineteen years were most likely to have had training (Table 1). Around one-half of twenty to twenty-five-year-olds were confident about their ability to manage once resettled and refused training. Eighty-three per cent were rehoused in social housing (56 per cent local authority, 27 per cent housing association), and 17 per cent in private-rented accommodation. Eighty-seven per cent had self-contained accommodation, and 13 per cent a 'bedsit' with a single room and shared kitchen and bathroom. 


\section{The resettlement accommodation}

For many, the first few weeks after moving were a struggle. Most relied on a Community Care Grant (CCG) to buy furniture and household goods but did not receive it until several weeks after moving. Hence, two-thirds were initially without a bed, cooker and basic household equipment. Several also moved to properties in disrepair, and 19 per cent were without electricity or gas. Many social housing landlords required occupation a few days after signing the tenancy agreement (or else the tenant lost the nomination), leaving insufficient time for CCG applications to be processed and the utilities to be connected. The young participants were more likely to be allocated accommodation in poor condition than those aged twenty-six-plus years.

Over the ensuing months many acquired furniture, household goods, personal possessions and created a 'home'. At fifteen/eighteen months, three-quarters of the young people said that their accommodation 'felt like home' (80 per cent of social housing tenants and 44 per cent of private-renters). Having a sense of control, having decorated and personalised the accommodation and feeling safe and comfortable were associated with the sense of homeliness. The main reasons for not regarding the accommodation as home were continuing maintenance problems and having insufficient funds to decorate and furnish. The range of their experiences is evident from two contrasting reports:

I love the flat. I've settled down and bought a lot of things to make it look like home. I can have family and friends over. I can come and go as I please.

There are too many problems with the place. It's in awful condition and it's impossible to get repairs done. It's not worth paying out to decorate or furnish it as I don't want to stay here. I'm used to living in a comfortable place - this is not homely, it's like a squat.

\section{Household tasks and finances}

Most coped well with basic household tasks, i.e. cooking and cleaning. Some regularly visited their parents and were given meals and assistance with laundry. Nearly onehalf of seventeen- to nineteen-year-olds still had this help at fifteen/eighteen months. Managing finances was, however, a serious and persistent problem for both the London and Notts/Yorks participants. Most were unemployed and reliant on welfare benefits. They received Council Tax Benefit (CTB) and a rent subsidy (Housing Benefit: HB), which covered most of the rent, but had to pay for gas, electricity and water. Nearly one-half received small sums from their parents in emergencies, for example for food or electricity, but few had more substantial financial help. Some said that their family could not afford to help, and some had not told their relatives about their difficulties.

Forty-three per cent had debts at the time of resettlement, and 76 per cent at fifteen/eighteen months. Across all age groups, financial problems developed fastest among seventeen- to nineteen-year-olds: they were the least likely to have debts when first resettled (29 per cent) and the most likely to have them at fifteen/eighteen months (79 per cent). Private-renters were particularly prone to increasing debts (affecting 90 per cent by fifteen/eighteen months). Several factors led to the proliferation of debts. Some took out loans to buy new furniture for their home. A few started university courses, at which point they lost their entitlement to welfare benefits and HB. For some, old court 
fines, rent arrears and other debts resurfaced once they had a fixed address. There was also a strong link between employment patterns and debts (discussed later). Their financial struggles are apparent from their comments:

I work 12 hours a day and seven days a week. I'm really tired when I get home; I've no time to socialise or phone my friends, I hardly see them. Most of my money goes on bills. I cannot afford to stay here.

I'm still on benefits as I can't find work. I've still a lot of decorating to do but I don't have the money to do it. I have no furniture except a bed. Budgeting is a problem and paying the bills. I stay at friends over the weekend as there is nothing in my flat - I don't even have a TV.

\section{Employment}

Twenty-one per cent of the young people were working full- or part-time at the time of resettlement, and 32 per cent by fifteen/eighteen months. Forty per cent of the London participants compared to 20 per cent of the Notts/Yorks participants were employed at fifteen/eighteen months $\left(\chi^{2}=3.86\right.$; degrees of freedom (df) $\left.1 ; p<0.05\right)$. Most were keen to work but struggled to find jobs, and were frequently in and out of work: 59 per cent worked at some time after being rehoused. Several obtained temporary or casual jobs through an agency or friends as, for example, labourers or security workers, but these were low paid and had irregular hours. The main reasons they gave for wanting a job were financial and to be independent and self-supporting:

Working and earning money gives me confidence and strength. Work is powerful. My friends and family respect me when I'm working.

Now I have a job I am financially independent and can pay my rent and buy food. This was not the case when I was on benefits.

Among those who were unemployed at fifteen/eighteen months, 29 per cent had attended welfare-to-work programmes since being resettled but this had not led to sustained, secure employment. There was a strong association between employment patterns and financial problems. Those who worked intermittently after being rehoused were most likely to accrue debts and be threatened with eviction for rent arrears (Table 2). When they started a job their HB, CTB and welfare benefits were stopped or reduced, but when jobs ended getting these reinstated was problematic. In contrast, the consistently unemployed regularly received welfare benefits and their rent was largely covered by HB.

\section{Tenancy support}

Tenancy support teams are funded by local authorities and directly by the DCLG to help formerly homeless and vulnerable people set up new tenancies and adjust to independent living. Only 28 per cent of the young people (and only 14 per cent in London) received help from a tenancy support (TS) worker, compared to 58 per cent of the participants 
Table 2 Financial situation of the young FOR-HOME participants at 15/18 months by employment status

\begin{tabular}{|c|c|c|c|c|}
\hline \multirow[b]{2}{*}{ Financial situation } & \multicolumn{4}{|c|}{ Employment pattern } \\
\hline & Employed $^{1}$ & Unemployed $^{2}$ & $\begin{array}{l}\text { Intermittently } \\
\text { employed }^{3}\end{array}$ & All \\
\hline & \multicolumn{4}{|l|}{ Percentages } \\
\hline Had debts at $15 / 18$ months $^{4}$ & 65 & 77 & 91 & 77 \\
\hline - rent arrears in last 12 months & 54 & 53 & 81 & 61 \\
\hline - rent arrears at $15 / 18$ months & 32 & 35 & 67 & 43 \\
\hline \multirow[t]{2}{*}{ Eviction threat $^{5}$} & 36 & 46 & 67 & 49 \\
\hline & Amount $(£$ & & & \\
\hline $\begin{array}{l}\text { Mean weekly income at } \\
15 / 18 \text { months }\end{array}$ & 192 & 69 & 73 & 109 \\
\hline Mean rent arrears at $15 / 18$ months & 166 & 233 & 371 & 247 \\
\hline Number of participants & (26) & (34) & $(21)$ & (81) \\
\hline $\begin{array}{l}\text { Notes } \\
{ }^{1} \text { Full-time or part-time. } \\
2 \text { Since being resettled. } \\
{ }^{3} \text { Worked intermittently since being r } \\
{ }^{4} \text { Includes rent arrears. } \\
{ }^{5} \text { Since being resettled. }\end{array}$ & ttled, but unen & loyed at $15 / 18 n$ & onths. & \\
\hline
\end{tabular}

aged twenty-six-plus years $\left(\chi^{2}=25.1\right.$, df $\left.1, p=0.000\right)$. The young participants were least likely to have had experience of independent living yet least likely to have received tenancy support. This anomaly arises partly because relatively few young people slept rough (on the streets) before entering hostels, and in London the DCLG-funded tenancy sustainment teams concentrate only on former rough sleepers. Among those that had TS, the most common help was with welfare benefit claims, rent arrears and repair problems, and three-quarters of these said the help was beneficial. Among those without TS, 37 per cent sought help from their former hostel when they had difficulties and a few used local advice centres. They tended to wait, however, until problems became serious and their tenancies were at risk.

\section{Housing outcomes and the influential factors}

After fifteen/eighteen months, 69 per cent of those aged seventeen to twenty-five were in their original accommodation, 13 per cent had moved to another tenancy and 18 per cent (twenty people) were without a tenancy. The outcomes were similar to those for other age groups: 82 per cent aged seventeen to twenty-five and 88 per cent aged twenty-six-plus still had a tenancy at fifteen/eighteen months. Among the young people who were without a tenancy, seven had been evicted for rent arrears, and the rest left the accommodation because of its poor condition, problems with the landlord or other tenants or harassment from locals. The Notts/Yorks participants were more likely to have moved to another tenancy (which was cheaper or more spacious) or to be without accommodation 
(17 per cent and 31 per cent respectively): the equivalent London figures were 9 per cent and 7 per cent. The lower rate of changing tenancy in London was likely because of the exceptional shortages of accommodation and high rents in the city. The higher rate of tenancy failure among the Notts/Yorks participants was related to their more chaotic histories (see below).

There were significant tenure differences, with private-renters much more likely to have moved or to be without a tenancy: 29 per cent were still in their original accommodation at fifteen/eighteen months, 29 per cent had moved to another tenancy and 41 per cent were without a tenancy (the equivalent percentages for social housing tenants were 77, 9 and 14). There were several reasons for this. The average weekly rents of the private-renters were nearly twice as high as those of social housing tenants, and several experienced financial difficulties when they started work as their HB was stopped or reduced. The private-rented tenancies were mainly bedsits (one room with a shared kitchen and bathroom) and the least desired accommodation, as they provided little space or privacy and conflicts sometimes occurred over sharing facilities. Poor property maintenance was another concern for the private-renters. Social housing providers have systems by which tenants request repair work and make complaints, while many privaterenters experienced difficulty getting the landlord to do repairs but were reluctant to complain for fear of jeopardising their tenancy (cf. Lister, 2006).

There were strong associations between the type of accommodation pre-resettlement, duration of stay and housing outcomes (Table 3). Those who had been in their last hostel or supported housing longer than six months, and in semi-independent accommodation before resettlement, were more likely to retain a tenancy than those who had shorter stays and/or slept rough intermittently during the preceding twelve months. Only 56 per cent who stayed in the pre-resettlement accommodation three months or less retained a tenancy, compared to 100 per cent who stayed more than twenty-four months. Longer stays extend the opportunities to access support services and professional help, to build life skills and confidence and to engage in education and training. There was a significant positive correlation between duration of stay and the amount of independent-living training received $(r=+0.19, p<0.05)$.

Having educational or vocational qualifications had a positive influence on tenancy sustainment. Those with qualifications showed more motivation, optimism and ambition before and after resettlement. They were more likely to have stayed in the pre-resettlement accommodation longer, to have participated in life-skills training and to be involved in education, training or employment at the time of resettlement. A history of illegal drug use had a negative influence on remaining housed, but being in care as a child, mental health, alcohol and literacy problems had no significant influence. Although managing finances was a major problem, there was no association between debts and tenancy sustainment. This may be because it can take months to accumulate large rent arrears and for housing providers to take action. By fifteen/eighteen months, 43 per cent who were still housed had rent arrears (a few owed $£ 1,000+$ ), and 27 per cent had been given 'a final warning' or were in the process of being evicted (but too few evictions had occurred to establish a relationship with debts). Family support, particularly practical help, also had a positive relationship on tenancy sustainment (Table 3). A study of homeless young people in Dublin similarly found that family contact, and particularly practical and emotional support, helped homeless young people to cope with the challenges they faced when exiting homelessness (Mayock et al., 2011). 
Table 3 Bivariate associations between personal characteristics, resettlement preparation, and remaining housed at $15 / 18$ months

\begin{tabular}{|c|c|c|c|c|}
\hline Characteristics & $\begin{array}{l}2 \\
\text { Still } \\
\text { housed } \\
\quad \text { Preval }\end{array}$ & $\begin{array}{l}3 \\
\text { No } \\
\text { tenancy } \\
\text { nce perce }\end{array}$ & $\begin{array}{l}\text { All } \\
\text { ages }\end{array}$ & $p^{1}$ \\
\hline \multicolumn{5}{|l|}{ Biographical and behavioural } \\
\hline Has educational/vocational qualifications & 75.0 & 42.1 & 68.9 & 0.005 \\
\hline History of illegal drug use & 41.7 & 84.2 & 49.5 & 0.001 \\
\hline Current homeless episode $>24$ months & 44.0 & 15.8 & 38.8 & 0.022 \\
\hline Slept rough in preceding 12 months $^{2}$ & 3.6 & 47.4 & 11.8 & $\#$ \\
\hline \multicolumn{5}{|l|}{ Resettlement preparation and housing } \\
\hline In last hostel/housing project $>6$ months ${ }^{2}$ & 73.5 & 21.1 & 63.7 & 0.000 \\
\hline In semi-independent accommodation ${ }^{2}$ & 79.3 & 38.9 & 72.0 & 0.001 \\
\hline Training on cleaning/looking after a home & 39.3 & 10.5 & 34.0 & 0.017 \\
\hline Training on budgeting/managing money & 53.6 & 21.1 & 47.6 & 0.010 \\
\hline Training on paying bills & 53.6 & 26.3 & 48.5 & 0.032 \\
\hline Moved to private-rented accommodation & 11.9 & 36.8 & 16.5 & $\#$ \\
\hline \multicolumn{5}{|l|}{ Family contact } \\
\hline Saw $1+$ family members at least monthly ${ }^{3}$ & 77.4 & 52.6 & 72.8 & 0.029 \\
\hline Family provided practical help ${ }^{3}$ & 60.7 & 26.3 & 54.4 & 0.007 \\
\hline Number of participants & 84 & 19 & 103 & \\
\hline
\end{tabular}

Notes: Column 2 has the percentages of those still housed (in the resettlement accommodation or a new tenancy) that reported each attribute.

Column 3 has the equivalent percentages of those that no longer had a tenancy.

Column 4 has the percentages of the sample that reported the attributes.

${ }^{1}$ For the chi-squared statistics from $2 \times 2$ frequency tables ( 1 degree of freedom);

\# Expected frequency in one cell too small $(<5)$ to calculate a reliable $p$ value.

${ }^{2}$ Immediately before being resettled.

${ }^{3}$ During the first six months after being resettled.

Stepwise logistic regression was used to examine the most significant multivariate influences on whether a young person was still housed after fifteen/eighteen months. The independent variables that associated significantly with tenancy sustainment (listed in Table 3) were entered into the model, and five were retained in the regression. The model was highly significant $(p=0.000)$ and correctly predicted 91.2 per cent of the cases (Table 4). Strong positive influences were having educational or vocational qualifications, the most recent homeless episode lasting longer than twenty-four months (indicating longer stays in hostels and temporary supported housing) and practical help from family during the first six months post-resettlement. The negative influences were a history of illegal drug use and having slept rough during the twelve months before resettlement.

\section{Policy and practice implications}

Most young FOR-HOME participants were glad to have been resettled and sustained a tenancy despite many difficulties. As with the all-age sample (Warnes et al., 2013), those 
Table 4 Stepwise logistic regression model of housing outcomes at 15/18 months

\begin{tabular}{|c|c|c|c|c|}
\hline Variables and model statistics & B & $\operatorname{Exp}(B)$ & $\begin{array}{l}95 \% \mathrm{Cl} \text { for } \\
\operatorname{Exp}(\mathrm{B})\end{array}$ & $p$ \\
\hline \multicolumn{5}{|c|}{ In accommodation (resettlement or new tenancy) at $15 / 18$ months $(N=102)$} \\
\hline Constant & 1.294 & 3.647 & & 0.099 \\
\hline $\begin{array}{l}\text { Slept rough in } 12 \text { months preceding } \\
\text { resettlement }\end{array}$ & -3.878 & 0.021 & $0.002-0.175$ & 0.000 \\
\hline History of illegal drug use & -2.938 & 0.053 & $0.007-0.422$ & 0.006 \\
\hline $\begin{array}{l}\text { Has educational or vocational } \\
\text { qualifications }\end{array}$ & 2.524 & 12.478 & $1.929-80.705$ & 0.008 \\
\hline $\begin{array}{l}\text { Practical help from family during first six } \\
\text { months }\end{array}$ & 2.736 & 15.425 & $1.953-121.816$ & 0.009 \\
\hline Last homeless episode $>24$ months & 1.870 & 6.488 & $0.923-45.616$ & 0.060 \\
\hline \multicolumn{5}{|l|}{$\begin{array}{l}\text { Model statistics: } \\
91.2 \% \text { correctly predicted } \\
\left.\chi^{2} 50.97 \text { (df } 5, p=0.000\right),-2 \log \\
\quad \text { likelihood } 47.11\end{array}$} \\
\hline
\end{tabular}

Notes: Cl: confidence interval. df: degrees of freedom.

The model correctly predicted 96.4 per cent in accommodation and 68.4 per cent without a tenancy.

who moved into the private-rented sector (PRS) had the poorest outcomes. Until recently, it was common for single homeless people in England to be resettled into social housing, but mounting shortages have led successive governments increasingly to advocate the use of the PRS. The suitability of PRS accommodation for vulnerable people has been questioned because of the short tenancies, poor condition and high rents of some properties (Rugg and Rhodes, 2008), yet it is increasingly the only move-on option for homeless young people. Apart from care-leavers aged under twenty-one, young people who move into the PRS and rely on $\mathrm{HB}$ are also only entitled to the 'shared accommodation rate', i.e. the cost of a single room with shared kitchen and bathroom.

It is therefore increasingly important that homelessness sector staff manage the moveon housing expectations of homeless young people, and advise them about realistic housing options and ways of overcoming difficulties such as sharing kitchens and bathrooms. Among the all-age FOR-HOME sample, more favourable housing outcomes were seen among those resettled through a 'managed' PRS scheme, whereby ongoing support was given to both tenants and landlords (72 per cent were still housed at fifteen/eighteen months). These findings suggest that such schemes are more effective for vulnerable people. The DCLG (2012) has made $£ 10.8$ million available to support the voluntary sector to deliver PRS schemes, and some are exclusively for young people.

Financial difficulties were common and persistent among the young FOR-HOME people, and led to increasing rent arrears and other debts. They had the same household expenses as other age groups but had to budget with a lower 'minimum wage' or lower rate of unemployment benefit. Compared to other age groups, young people generally have low financial literacy, high rates of impulsive spending and a 'live for 
today' attitude (Atkinson and Kempson, 2004; Heath, 2008). More advice needs to be available for homeless young people before and after resettlement about day-to-day money management, the payment of household bills, tackling debts and the financial implications of taking loans or making changes such as entering full-time education or taking on part-time or temporary work. At the time of FOR-HOME, few homelessness organisations in England had specialist financial advice teams. During workshops with front-line staff, several explained that they lacked the knowledge and skills to advise on strategic financial planning. In another study, 89 per cent of homeless young people surveyed in 2011 believed that training in financial skills was important (Centrepoint, 2011).

The difficulty of gaining steady employment and the instability of casual and temporary work contributed to the young participants' financial problems. Youth unemployment is a serious problem in Britain: in mid-2012 one-fifth of sixteen- to twentyfour-year-olds were unemployed (Rhodes, 2012). For those who have been homeless, the problem is more profound (see Centrepoint, 2012). The young FOR-HOME participants were competing for jobs at a time of high unemployment, and were further disadvantaged by their support needs and few qualifications: 41 per cent in FOR-HOME, compared to 8 per cent of sixteen- to twenty-four-year-olds in England in 2006, had no qualifications (Department for Education and Skills, 2007: Table 1).

Numerous government initiatives have been introduced over the last two decades to encourage unemployed people into work, but their effectiveness in helping young vulnerable people is unknown. Between 2009/10 and 2010/11, the number of 'starts' in apprenticeship schemes increased by 299 per cent among people aged twenty-five-plus years, compared to just 24 per cent among nineteen- to twenty-four-year-olds (Department for Business, Innovation and Skills, 2012). Several FOR-HOME participants attended welfare-to-work programmes, but this did not lead to sustained employment. More jobskills training and help to find work needs to be available for homeless young people, whether through homelessness sector organisations or welfare-to-work contractors who recognise and respond to their additional needs.

The benefits of staying in supported accommodation for several months before resettlement is shown by the FOR-HOME data, yet this is being jeopardised by funding cuts to homelessness services (Crane et al., 2012). Until recently, the principal budget for housing support services was Supporting People (SP). The funds were originally ringfenced, but from April 2011 were aggregated into the 'local authority Formula Grant' with no allocation specific for SP services. This has greatly increased local authorities' discretion about how they allocate the funds. Some have shortened maximum hostel stays (to three or six months) or limited how long a person can remain on the 'housing support pathway'. As a result, some homeless young people move into independent accommodation before they are ready.

The importance of tenancy support for young people in independent accommodation has been acknowledged by the Ministerial Working Group on Homelessness (DCLG, 2012), yet long waiting lists and strict allocation criteria meant that it was unavailable to the majority of young FOR-HOME participants. Some sought help from their former hostel or a local advice centre when they were having difficulties, but the hostel staff rarely had the capacity to give substantial help, particularly if their problems were complex and required extended interventions. At the same time, many youth advice services have either closed or been cut (Homeless Link, 2012; Youth Access, 2012). Other ways to provide 
post-resettlement advice and help to homeless young people should be explored, such as the use of mentors and 'drop-in' sessions at selected sites.

\section{Conclusions}

For any young person, the transition to independent living is not easy, and it is extremely challenging for those who have been homeless and are without financial resources or strong family support. In the UK, given the economic recession, high housing costs, expenditure cuts and welfare benefit changes, the challenges and struggles for homeless young people who are resettled are likely to worsen. Adequate affordable housing is a necessary condition for their successful resettlement, yet there is a serious shortage, particularly in London. The rhetoric that parents/guardians should continue to house and support their offspring until they achieve financial independence increasingly prevails, and mooted proposals for welfare benefit reforms have included scrapping HB for undertwenty-fives. Living with parents is not, however, an option for many homeless young people.

Over the coming years there is likely to be increasing competition for PRS tenancies, and young people will be 'further marginalised within a badly functioning housing system' (Clapham et al., 2012: 8). Cuts to housing subsidies for PRS tenants since April 2011 have made it harder for low-income people to find accommodation as they are required to meet any shortfall in rent, and an extension in January 2012 of the HB 'shared accommodation rate' $^{\prime}(\mathrm{SAR})$ restriction to those aged under thirty-five years has further increased the demand for shared housing. Furthermore, many landlords refuse to let to young people and HB claimants (Centre for Housing Policy, 2011). A survey in November 2012 of PRS vacancies in Birmingham, Leeds and an outer London Borough found that only 13 per cent of 4,360 shared properties were affordable within the SAR, and just 1.5 per cent accepted SAR recipients (Sanders and Teixeira, 2012).

More needs to be done to ensure there is a coherent package of housing and support for young people who are unable to live with relatives. Rugg (2010) proposed the creation of 'hotels' by social housing providers for young people on low-incomes who are in their first jobs. The Ministerial Working Group on Homelessness made a similar proposal, for shared student style accommodation with 'light touch' support for young people in full-time education, employment or an apprenticeship (DCLG, 2012). Others believe that the PRS is the solution to young people's housing, and suggest tax advantages for private landlords, as in Germany and France, in return for stipulations about the target population, rent levels and security of tenure (Oxley et al., 2010; Clapham et al., 2012). Centrepoint proposes the expansion of social lettings agencies to help young people access the PRS, whereby local authorities lease properties from private landlords and sublet to low-income households in housing need (Centrepoint, 2010).

Access to training and employment opportunities are crucial if homeless young people are to avoid even more serious financial difficulties once resettled, particularly given welfare benefit changes. For example, a cut in the annual budget for Council Tax Benefit since April 2013 means that many young people on benefits must now contribute to their council tax bill, and in October 2013 a new single welfare benefit (Universal Credit) will be introduced to replace several benefits. It will be paid monthly rather than two-weekly (as is the current practice) so effective budgeting will be even more critical. 
The FOR-HOME study had both strengths and limitations. It concerned only young people who moved to independent housing, not those with more complex problems or challenging behaviour who moved to specialist supported housing or left hostels without being resettled. The sample was drawn from just three areas of England. FOR-HOME involved homeless young people resettled just before the major welfare cuts started, and they were interviewed for only eighteen months after resettlement. More studies are needed to determine the long-term outcomes of resettlement, and the effectiveness of resettlement practices in the current economic climate. Evaluations are also needed of the suitability of various housing options for vulnerable and disadvantaged young people, and of the effectiveness of various programmes and services to meet their financial, training and employment needs.

\section{Acknowledgements}

The authors thank the staff of the collaborating organisations for their critical contributions to the FOR-HOME study (Broadway, Centrepoint, St Mungo's and Thames Reach in London; Framework in Nottinghamshire; and St Anne's Community Services in Yorkshire). We are also indebted to the participants and to other members of the research team. The study was funded by the UK Economic and Social Research Council (grant RES-062-230255).

\section{References}

Atkinson, A. and Kempson, E. (2004) Young People, Money Management, Borrowing and Saving, London: Banking Code Standards Board.

Benjaminsen, L. and Busch-Geertsema, V. (2009) 'Labour market reforms and homelessness in Denmark and Germany: dilemmas and consequences', European Journal of Homelessness, 3, 127 53.

Broadway (2012) Street to Home Annual Report: 1st April 2011 to 31st March 2012, London: Broadway. Broadway (2013) Street to Home: 1st April 2012 to 31st March 2013, London: Broadway.

Cauce, A. M., Paradise, M., Embry, L., Morgan, C. J., Lohr, Y. and Theofelis, J. (2000) 'The characteristics and mental health of homeless adolescents: age and gender differences', Journal of Emotional and Behavioral Disorders, 8, 4, 230-9.

Centre for Housing Policy (2011) Unfair Shares: A Report on the Impact of Extending the Shared Accommodation Rate of Housing Benefit, York: Centre for Housing Policy, University of York.

Centrepoint (2010) The Changing Face of Youth Homelessness: Trends in Homeless Young People's Support Needs, London: Centrepoint.

Centrepoint (2011) Moving on or Just Moving Out? Resettling Homeless Young People into Independent Accommodation, London: Centrepoint.

Centrepoint (2012) Opportunity Lost? The Experiences of Homeless Young People in Accessing Education, Training and Employment, London: Centrepoint.

Chamberlain, C. and MacKenzie, D. (2004) Youth Homelessness: Four Policy Proposals, Melbourne, Victoria: Australian Housing and Urban Research Institute.

Clapham, D., Mackie, P., Orford, S., Buckley, K., Thomas, I., Atherton, I. and McAnulty, U. (2012) Housing Options and Solutions for Young People in 2020, York: Joseph Rowntree Foundation.

Crane, M., Warnes, A. M. and Coward, S. (2011) Moves to Independent Living: Single Homeless People's Experiences and Outcomes of Resettlement, Sheffield: Sheffield Institute for Studies on Ageing, University of Sheffield. 
Crane, M., Warnes, A. M. and Coward, S. (2012) 'Preparing homeless people for independent living and its influence on resettlement outcomes', European Journal of Homelessness, 6, 2, 17-45.

Department for Business, Innovation and Skills (BIS) (2012) Post-16 Education and Skills: Participation, Outcomes and Level of Highest Qualification Held, Quarterly statistical first release, DS/SFR16, London: Data Service, BIS.

Department for Communities and Local Government (DCLG) (2006) Places of Change: Tackling Homelessness Through the Hostels Capital Improvement Programme, London: DCLG.

DCLG (2007) Tackling Youth Homelessness, Policy briefing 18, London: DCLG.

DCLG (2012) Making Every Contact Count: A Joint Approach to Preventing Homelessness, London: DCLG.

Department for Education and Skills (DFES) (2007) The Level of Highest Qualification Held by Adults: England 2006, London: DFES.

Fowler, P. J., Toro, P. A. and Miles, B. W. (2009) 'Pathways to and from homelessness and associated psychosocial outcomes among adolescents leaving the foster care system', American Journal of Public Health, 99, 8, 1453-8.

Gomez, R., Thompson, S. J. and Barczyk, A. N. (2010) 'Factors associated with substance use among homeless young adults', Substance Abuse, 31, 1, 24-34.

Hagan, J. and McCarthy, B. (2005) 'Homeless youth and the perilous passage to adulthood', in D. W. Osgood, E. M. Foster, C. Flanagan and R. G. Ruth (eds.), On Your Own Without a Safety Net: The Transition to Adulthood for Vulnerable Populations, Chicago: University of Chicago Press, pp. 178-201.

Heath, S. (2008) Housing Choices and Issues for Young People in the UK, York, UK: Joseph Rowntree Foundation.

Holmes, J. (2008) Making a Difference: Supported Lodgings as a Housing Option for Young People, London: DCLG.

Homeless Link (2011) Young and Homeless: A Survey of Services and Local Authorities, London: Homeless Link.

Homeless Link (2012) Young and Homeless 2012, London: Homeless Link.

Hutson, S. and Liddiard, M. (1994) Youth Homelessness: The Construction of a Social Issue, Basingstoke: Macmillan.

Kurtz, D. P., Lindsey, E. W., Jarvis, S. and Nackerud, L. (2000) 'How runaway and homeless youth navigate troubled waters: the role of formal and informal helpers', Child and Adolescent Social Work Journal, $17,5,381-402$.

Lister, D. (2006) 'Unlawful or just awful? Young people's experiences of living in the private rented sector in England', Nordic Journal of Youth Research, 14, 2, 141-55.

Lovatt, R., Whitehead, C. M. E. and Levy-Vroelant, C. (2006) 'Foyers in the UK and France: comparisons and contrasts', European Journal of Housing Policy, 6, 2, 151-66.

Mallett, S., Rosenthal, D. and Keys, D. (2005) 'Young people, drug use and family conflict: pathways into homelessness', Journal of Adolescence, 28, 2, 185-99.

Mallett, S., Rosenthal, D., Keys, D. and Averill, R. (2010) Moving Out, Moving On: Young People's Pathways In and Through Homelessness, London: Routledge.

Mayock, P., Corr, M. L. and O'Sullivan, E. (2011) 'Homeless young people, families and change: family support as a facilitator to exiting homelessness', Child and Family Social Work, 16, 4, 391-401.

Milburn, N. G., Rosenthal, D., Rotheram-Borus, M. J., Mallett, S., Batterham, P., Rice, E. and Solorio, R. (2007) 'Newly homeless youth typically return home', Journal of Adolescent Health, 40, 6, 574-6.

Milburn, N. G., Rosenthal, D., Rotherham-Borus, M. J., Mallett, S., Rosenthal, D., Batterham, P., May, S. J., Witkin, A. and Duan, N. (2009) 'Adolescents exiting homelessness over two years: the risk amplification and abatement model', Journal of Research on Adolescence, 19, 4, 762-85.

Nebbit, V., House, L., Thompson, S. J. and Pollio, D. E. (2007) 'Successful transitions of runaway/homeless youth from shelter care', Journal of Child and Family Studies, 16, 4, 545-55.

Osgood, D. W., Foster, E. M. and Courtney, M. E. (2010) 'Vulnerable populations and the transition to adulthood', The Future of Children, 20, 1, 209-29. 
Oxley, M., Lishman, R., Brown, T., Haffner, M. and Hoekstra, J. (2010) Promoting Investment in Private Rented Housing Supply: International Policy Comparisons, London: DCLG.

Quilgars, D. (2010) 'Youth homelessness', in E. O'Sullivan, V. Busch-Geertsema, D. Quilgars and N. Pleace (eds.), Homelessness Research in Europe, Brussels: FEANTSA, pp. 187-210.

Quilgars, D., Fitzpatrick, S. and Pleace, N. (2011) Ending Youth Homelessness: Possibilities, Challenges and Practical Solutions, York and Edinburgh: Centre for Housing Policy, University of York and School of the Built Environment, Heriot-Watt University.

Rhodes, C. (2012) Youth Unemployment Statistics, Briefing Paper: SN/EP/5871, London: House of Commons Library.

Rugg, J. (2010) Young People and Housing: The Need for a New Policy Agenda, York: Jospeh Rowntree Foundation.

Rugg, J. and Rhodes, D. (2008) The Private-Rented Sector: Its Contribution and Potential, York, Centre for Housing Policy, University of York.

Sanders, B. and Teixeira, L. (2012) No Room Available: Study of the Availability of Shared Accommodation, London: Crisis.

Tevendale, H. D., Comulada, W. S. and Lightfoot, M. A. (2011) 'Finding shelter: two-year housing trajectories among homeless youth', Journal of Adolescent Health, 49, 6, 615-20.

Toro, P. A., Dworsky, A. and Fowler, P. J. (2007) 'Homeless youth in the United States: recent research findings and intervention approaches', in D. Dennis, G. Locke. and J. Khadduri (eds.), Toward Understanding Homelessness: The 2007 National Symposium on Homelessness Research, Washington, DC: US Department of Health and Human Services and US Department of Housing and Urban Development, 6:1-6:33.

Warnes, A. M., Crane, M. and Coward, S. (2013) 'Factors that influence the outcomes of single homeless people's rehousing', Housing Studies, 28, 5, 782-98.

Youth Access (2012) Stretched to the Limit: Results of a Survey on the Funding Situation of Youth Information, Advice, Counselling and Support Services, London: Youth Access. 